\title{
Deterioration of blue Nile forests and its ecological effects in the Gezira State- Sudan
}

\begin{abstract}
The research aims to outline the major characteristics of forest cover in Greater Wad Madani and South Gezira Localities including the areas around the Blue Nile in the period 1973-2019 and analyze the apparent spatial and temporal attributes pertaining to species density, frequency and abundance and the causes of its deterioration and the impact of this deterioration on the ecosystem of the study area. To achieve these aims, digital data from satellite images taken by the U.S Land sat 5 and Land sat 7 for the years 1973, 2001 and 2016 were processed and analyzed using Erdas Imagine, Arc Map and GiS, whereby a quantitative and qualitative inventory of the forest cover is carried out using the square method to determine the percentage of coverage, density and abundance of tree species. The inventory showed clearly that diversity of tree species underwent clear decimation. Some species that were prevalent in the past became at the present few and rare such as Acacia nilotica, Acacia seyal vor seyal and Acacia nubica. Some of the species almost disappeared such as A.seyal vor fistula. Noteworthy, the Prosopis juliflora and Capparis decidua are beginning to be dominant unless measures are taken to combat their spread. An important indicator of the deterioration of forest cover is the decrease in the area of forests. While the forested area in the Locality comprised $14.7 \%$ of the total area of the study area in 1973 it decreased to $3.1 \%$ in 2016 . The main reasons behind this deterioration were the need of the population for wood for fuel purposes, construction, traditional industries and grazing. The research raised several recommendations which include the preparation of a comprehensive environmental database on land use which must include the forest cover in addition to establishment of an administrative monitoring and follow up organ equipped with modern technology to ensure the sustainable conservation of forests.
\end{abstract}

Keywords: deterioration, forest, ecology, acacia, coverage, density, frequency, abundance
Volume 5 Issue I - 2020

\section{Mohammed Ahmed HA Al Zubair, Sabah alkhair, MM Hamdan}

Geography, University of Khartoum, Sudan

Correspondence: Dr. Mohammed Ahmed HA Al Zubair, Associate professor, Geography, University of Khartoum, Sudan, Tel 002499|28I2040, Email abozake68@gmail.com

Received: December 19,2019 | Published: February I2, 2020

\section{Introduction}

There are several studies on estimates of the area of forests in Sudan bearing in mind that since early 1900s extensive areas of woodland and forest have been converted to agricultural use. ${ }^{1}$ Although Sudan used to have a large quantity of natural forest, studies have shown that by 1991 a large part of these forests remained almost unexploited. ${ }^{2}$ In the late $1970 \mathrm{~s}, \mathrm{FAO}^{3}$ estimated that the country's forests and woodlands totaled about $915,000 \mathrm{~km}^{2}$, or $38.5 \%$ of the land area. However, the Department of Forestry Management in the Gezira State in the mid-1970s, reported that the total forest cover was only $584,360 \mathrm{~km}^{2}$, or $24.6 \%$ of the country's land area. More than $129,000 \mathrm{~km}^{2}(25 \%)$ of this estimate were located in the dry and semiarid regions of northern Sudan. These forests were considered valuable chiefly as protection for land against desertification and served as a source of fuel for pastoral people living in the regions. ${ }^{4}$ However, the growing population pressure on the land resulted in an accelerated destruction of forestland and prompted steady encroachment of Sahara sand towards the south at a rate of about $10 \mathrm{~km} /$ year in the 1980s. ${ }^{5}$ Noteworthy, since 1983 , the civil war virtually halted forestry production in southern Sudan, from which came the overwhelming amount of forestry products. ${ }^{6}$ Similarly, the Acacia belts of the Nile were used intensively resulting in a rapid advance of deforestation. In 1990-1991 plans were underway to establish a forestry resource conservation project ${ }^{8}$ for the improvement of the running government forestry conservation and management policy and the issue of land use making use of several funds from international development agencies. In, 1983 the National Forestry Administration reported that the forestry area was 96 Million $\mathrm{Km}^{2}$. The level of destruction can easily be notices when this report are compared to the study of Bayoumi ${ }^{9}$ which indicated that the area of natural forests cover was $584,000 \mathrm{~km}^{2}$ in 1968 and then decreased to $559,000 \mathrm{~km}^{2}$ in 1980 and the report of World Bank (1986) which estimated the area to range between $18 \%$ and $23.4 \%$ of the total area of Sudan. ${ }^{10}$ On the other hand, Abdel Magid ${ }^{11}$ estimates that the forestry area in Sudan in 1990 at 429,76 hectares equivalent to $25.1 \%$ of the total area of Sudan while $\mathrm{FAO}^{3}$ estimated that the area of forest cover is $454 \mathrm{~km}^{2}$.

\section{The study area}

The study area lies between latitudes $\left(14^{\circ}, 20\right.$ and $14^{\circ}, 33$ North and longitudes $33^{\circ}, 26$ and $38^{\circ}, 33$ East and is bordered in the north by Hassahisa Locality and the Locality of Greater Wad Madani, the locality of South Gezira in the southern part of the State and in the west by the Locality of Manqel and South Sinner State and in the East by the Blue Nile. The total area of the study area is about $3214 \mathrm{~km}^{2}$ (Figure 1).

The geological setting of the study comprises three formations. On the top is the Gezira formation which covers about $80 \%$ of the study area, followed in some places by Basement rocks of Silurian age and in other places by the water-bearing OmRwaba formation which is a very narrow area near the Manqel Locality. The region lies within the 
light Savanna climate with average rainfall ranging between $250 \mathrm{~mm}$ in the North to $350 \mathrm{~mm}$ in the South. ${ }^{12}$

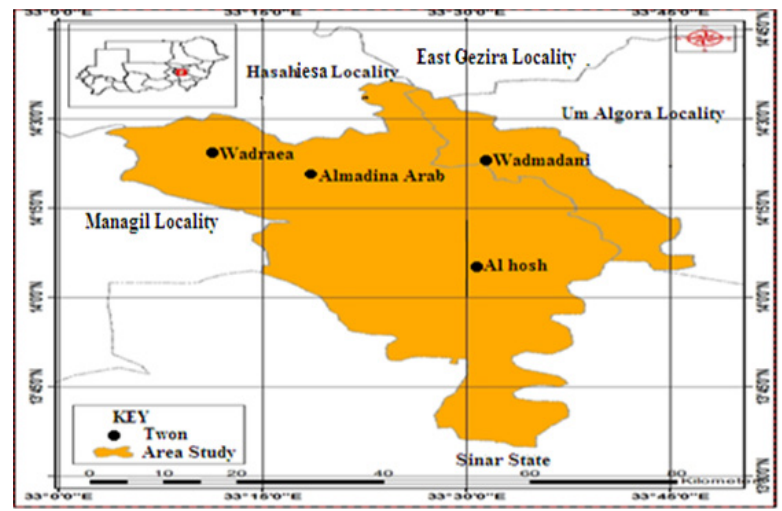

Figure I Location of the study area.

Usually starting in June until the end of September with $70 \%$ to $80 \%$ of it falling during the rainy season and decreases significantly in the dry season. ${ }^{13}$ Irrespective of small pediplains around rocky areas, the dominant soil type is clayey soils which cover about $81 \%$ of the area. Topographically, the study area represents a semi-flat or flat plain which gently slopes from the south to the north. The Blue Nile is the main artery to which surface water and seasonal valleys drain.

The total area of the Wad Madani Locality is 142,857.3 acres and forests along the Blue Nile cover an area of 5351 acres equivalent to $3.7 \%$ of the total area of Locality. In addition, there are other forested areas located near many small settlements (Figure 2). According to the Gezira State Forestry Administration (1995), there are also reserved and natural forests which cover not more than 3368 acres.

\section{Methodology}

The research is based on the analysis of three satellite images from the US satellite Land sat 5 and 7 for the years 1973, 2001 and 2016 (Figure 3) using GIS and Arc Maps. To facilitate the inventory process, two forests were selected from the study area, one representing natural forests and the other representing cultivated forests.

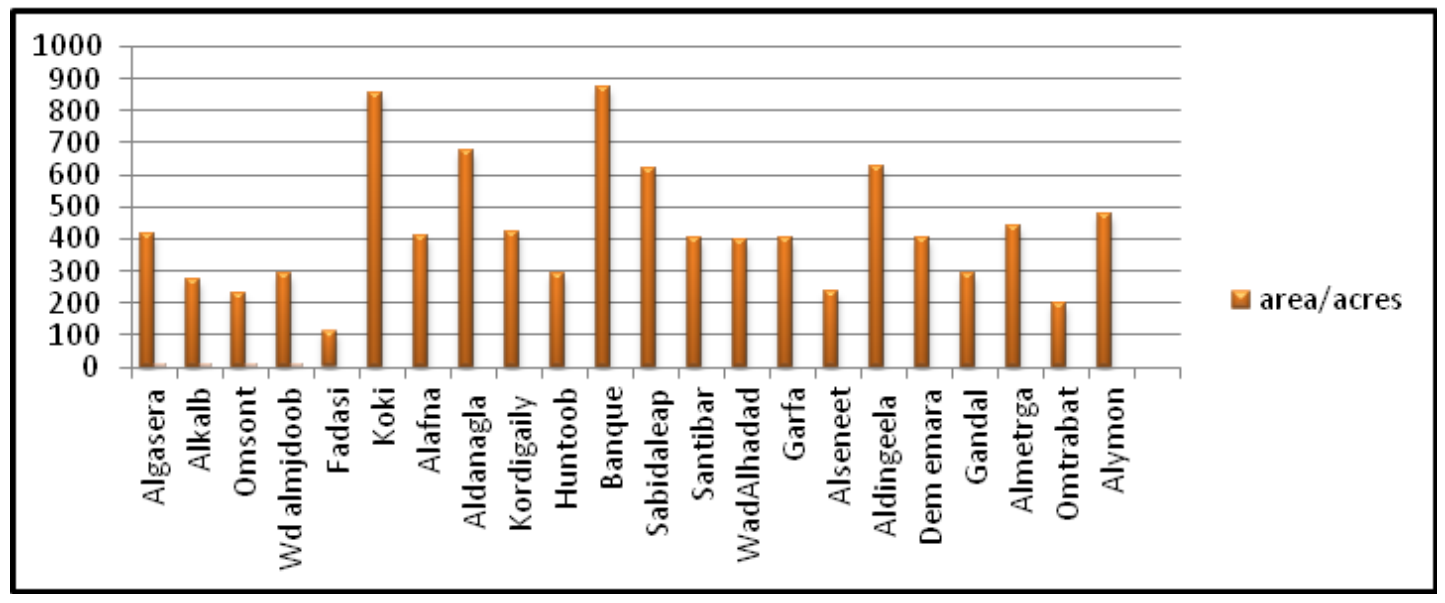

Figure 2 Forest area in the localities of Wad Madani and south Gezira.

Source: Information from Forestry Administration- Gezira State (19/8).
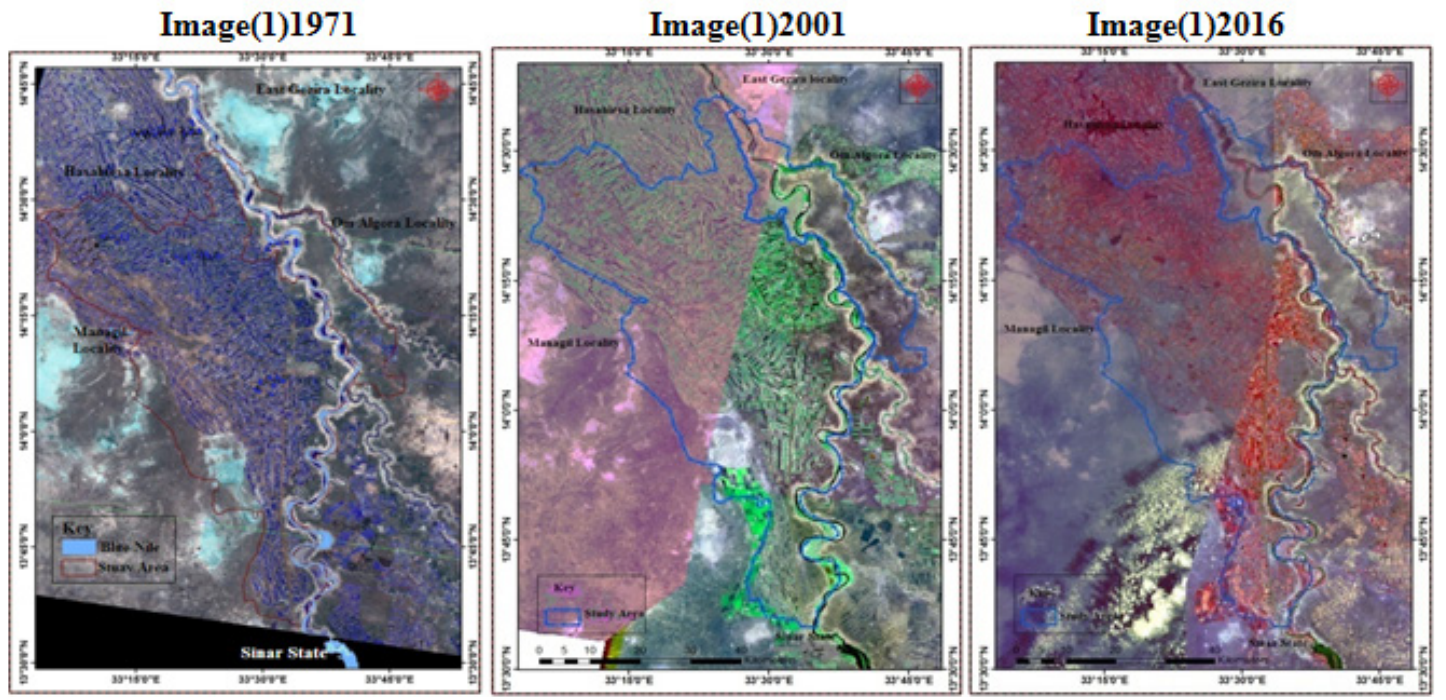

Figure 3 Images from the US satellite Land sat 5 and 7. 
The data collected for inventory based on the quadrate method usually used in vegetation field surveys to determine the density, frequency and abundance of plant species. Accordingly, the selected forests were divided into squares, each $100 \mathrm{~m} \times 100 \mathrm{~m}$, and from each squire samples of trees were collected according to the following scheme:

Specify the sample box $100 \mathrm{~m} \times 100 \mathrm{~m}=10,000 \mathrm{~m}^{2}$.

a. Identify a central location where the main and sub-directions of 8 directions.

b. Selection of 10 squares from each forest separated by distances ranging from $(2-3) \mathrm{km}$.

c. Inventory of vegetation in accordance with the laws set for this (Table 1).
Determination of cover, frequency, density abundance ratios:

$$
\text { Coverage }=\frac{\text { Number of one type of species }}{\text { Total number of species }}
$$

Frequently $=\frac{\text { Number quadrates } \text { where type }(\text { Acacia }) \text { is found } \times 100}{\text { Total number of quadrate studied }}$

$$
\text { Density }=\frac{\text { Number of species of one type }(A)}{\text { Total number of guadrate studies }}
$$

Abundance $=\frac{\text { Number of one type of species }(A)}{\text { Number of quadrate containing that species }}$

\begin{tabular}{|c|c|c|c|c|c|c|c|c|c|c|c|c|}
\hline \multirow{2}{*}{ Species } & $\mathbf{S}$ & $\mathbf{S}$ & $\mathbf{S}$ & $\mathbf{S}$ & $\mathbf{s}$ & \multirow{2}{*}{$\mathbf{N}$} & \multirow{2}{*}{ Notes } & \multirow{2}{*}{$\begin{array}{l}\mathrm{L} \\
\mathrm{cm}\end{array}$} & \multirow{2}{*}{ C\% } & \multirow{2}{*}{$\mathbf{A} \%$} & \multirow{2}{*}{$\begin{array}{l}F \\
p / s\end{array}$} & \multirow{2}{*}{$D \mathrm{p} / \mathrm{s}$} \\
\hline & I & 2 & 3 & 4 & 5 & & & & & & & \\
\hline A. nubica & 3 & - & 7 & - & 5 & 15 & - & 30 & 60 & 60 & 5 & 5 \\
\hline A. sayal & 5 & - & 5 & 5 & - & 40 & - & 15 & 45 & 80 & 10 & 10 \\
\hline
\end{tabular}

Table I Survey form that was applied to the study area

Where S, square; N, number of total species; C\%, coverage, L, plant length; F, frequency; A\%, abundance; $D$, density; P, plant

Source: Gharaibeh, Al-Farhan, I991.

\section{Reasons for degradation of forest resources}

According to the 1973 census, the population of Gezira State was 979,113 , and in 1983 it increased to $1,117,840$, and then to $2,715,605$ in $1993 .{ }^{14}$ The latest population estimates carried in 2017 rendered a figure of $3,575,280$ with a density of 137 per $\mathrm{km}^{2}$. The field survey (2018), estimated that $100 \%$ of local people reported that until the year 1990 they covered their needs for firewood, home furnishing and traditional industries from nearby forests of villages and cities. However, this dependence decreased to $65 \%$ in 2000 and then to $47 \%$ in 2017, possibly because they started to resort to other emerging alternatives.

We find that the average consumption of a family (5-10 persons) is about $100 \mathrm{Kg}$ of charcoal monthly, which is equivalent to 3 trees ranging in length from 3-5 meters, and has decreased to less than a tree at present in some areas. There were specific types of species that are usually felled more than others such as Acacia nilotica, Acacia seyal var seyal and Acacia Senegal. Of late, Eucalyptus as a cultivated species has entered to replace other species especially in building materials. The number of bakeries, which formerly depended on fire wood, has also increased, reaching 1171 in 2000, and began to switch to Gas and However, the unstable supply of Gas and electricity has recently forced the bakeries to return to the use of forest fuel again. The situation currently looks as follows: $55 \%$ of bakeries use wood, 3.5 electricity $26.5 \%$ use Gas.

\section{Inventory of natural and cultivated forests}

The results of the field work (2016-2017) indicated that there were more than four types of forests in the study area where $57 \%$ of the respondents stated that the forests species in their area were A.nilotica, and 22\% Eucalyptus trees, 6\% A.seyal var seyal, 13\%
A.seyal var fistula and $1 \%$ other species. The results of the field survey in (2018) are presented in (Table 2). (Local equivalents of Latin names of species are obtained from the Faculty of Forestry, University of Khartoum).

Table 2 Tree species in the cultivated and natural forest

\begin{tabular}{ll}
\hline Scientific name & Local name \\
\hline Acacia nilotica & Sunut \\
Balanites aegyptiaca & Higleeg \\
Acacia mellifera & Kiter \\
Acacia nubica & Laot \\
Capparis decidua & Tundub \\
Ziziphus spina -christi & Sider \\
Acacia seyal var fistula & Talh \\
Acacia senegal & Hashab \\
Acacia albida & Haraz \\
Acacia tortillis var raddiana & Seyal \\
Eucalyptus & Ban \\
Prosopis juliflora & Miskit \\
\hline
\end{tabular}

Source: Field Survey (2018) 


\section{Quantitative inventory of natural and cultivated forest trees}

Table 3 shows the quantitative inventory of species in the cultivated forests which are forests of Eucalyptus trees while Table 4 shows the values of trees in the natural forest in which Acacia nilotica dominates. We will outline first the different values of the prevalence of these species in terms of coverage, frequency, density and abundance and then compare these values with the forest cover in the past based on satellite images for the years (1973-2001-2016) and field survey (2018) to find out the quantitative and qualitative differences between them as follows:

i. Species in the table above are found within the cultivated forest, which is originally a forest consisting of Eucalyptus trees.

ii. We note that the Acacia nilotica, A.nubica, A.mellifera and Balanites aegyptiaca, are the most dominant

iii. It is clear that the least dominant trees are Capparis decidua with a cover of $3.3 \%$, and the abundance of $3.1 \mathrm{P} / \mathrm{S}$, and density of $2.2 \mathrm{P} / \mathrm{S}$, followed by Ziziphus spina -Christi with a coverage of $1.6 \%$, and abundance $1.8 \mathrm{P} / \mathrm{S}$, density $1.1 \mathrm{P} / \mathrm{S}$, followed by A.seyal var fistula with $9.5 \%$ coverage, abundance of $10.6 \mathrm{P} / \mathrm{S}$, and density $6.4 \mathrm{P} / \mathrm{S}$, followed by Acacia seyal vor seyal has a cover of $1.5 \%$, abundance of $2.5 \mathrm{P} / \mathrm{S}$, and density of $1 \mathrm{P} / \mathrm{S}$.

iv. We note that the cover in Capparis decidua, Ziziphus spinaChristi, Acacia seyal vor fistula do not exceed 5\%, except for Acacia seyal vor seyal where the coverage rate was $9.5 \%$.

v. In reference to field work (2016) the respondents mentioned that the dominant tree species in the study area are Acacia nilotica, Acacia seyal var fistula (Table 2 shows the presence of other species in the study area in 2017).

vi. The presence of these species in the cultivated forest despite the prevalence of Eucalyptus is evidence that they existed in the past.

vii. The presence of this cluster of trees is evidence of the diversity of trees .This is confirmed by satellite images for the years (1973, 2001 and 2016).

From Table 4:

a. The tree species in the table above are found in the natural forest, which is originally an Acacia nilotica forest. b. The most dominant trees are Acacia nubica with $36.9 \%$ coverage and an abundance of $51.6 \mathrm{p} / \mathrm{s}$ and density of $25.8 \mathrm{p} / \mathrm{s}$, followed by Capparis decidua with $33 \%$ coverage, and $46.2 \mathrm{p} / \mathrm{s}$ and a density of $23.1 \mathrm{p} / \mathrm{s}$. We note that the species Acacia nubica, Capparis decidua and Acacia tortillis exhibit a frequency of almost $50 \%$, while that of the rest is less than $50 \%$.

c. A noticeable scarcity of Acacia albida, Ziziphus spina- christi, Acacia seyal var seyal, Balanites aegyptiaca, Acacia mellifera and Prosopis juliflora with coverage not exceeding 5\% except for Acacia seyal var fistula which is $7.6 \%$.

d. The presence of all these species of low prevalence in the forest is evidence of the diversity of forest cover in the region. However, it must be noted that species diversity was more pronounced in the past in terms of quality and quantity as determined by the fieldwork 2016.

In comparing the model of the cultivated forest in (Table 3) with the natural forest in (Table 4), the following attributes can be identified:

i. Multiple species of trees in the cultivated forest and natural forest exist despite the rule of one species.

ii. The species in the natural forest, such as Acacia tortillis, Acacia albida, Prosopis juliflora are rarely found in the cultivated forest.

iii. The species Acacia tortillis, Acacia albida and Prosopis juliflora exhibit less cover and spread in the natural forest than in the planted forest.

iv. The natural forest exhibits less density and less abundance in tree species than in the cultivated forest.

v. The prevalence of trees in the past was very low.

vi. The scarcity of the spread of some species in the past to less than $0.7 \%$ cover such as Acacia mellifera, with a cover of $0.6 \%$, Prosopis juliflora with a cover of $0.4 \%$ and other species for $1 \%$.

vii. The emergence of exotic trees that have the ability to compete and spread but with low nutritional value such as Prosopis juliflora which demands urgent efforts to halt their spread.

Table 3 Quantitative inventory of trees in cultured forest

\begin{tabular}{llllll}
\hline Scientific name & Local name & Density P/S & Abundance P/S & Frequency \% & Cover \% \\
\hline Acacia nilotica & Sunut & 22,4 & 22,4 & 100 & 33,3 \\
Balanites aegyptiaca & Higleeg & 13,8 & 13,8 & 100 & 20,5 \\
Acacia mellifera & Kiter & 7,3 & 7,3 & 100 & 10,8 \\
Acacia nubica & Laot & 13 & 13 & 100 & 19,3 \\
Capparis decidua & Tundub & 2,2 & 3,1 & 70 & 3,3 \\
Ziziphus spina -christi & Sider & 1,1 & 1,8 & 60 & 1,6 \\
Acacia seyal var fistula & Talh & 6,4 & 10,6 & 60 & 9,5 \\
Acacia senegal & Hashab & 1 & 2,5 & 40 & 1,5 \\
\hline
\end{tabular}

P, plant; S, square

Source: Field Survey (2017) 
Table 4 Quantitative inventory of trees in natural forest

\begin{tabular}{llllll}
\hline Scientific Name & Local Name & Density & Cornucopia & Frequency \% & Coverage \% \\
\hline Acacia nubica & Sunut & 25,8 & 51,6 & 50 & 36,9 \\
Capparis deciduas & Tundub & 23,1 & 46,2 & 50 & 33 \\
Acacia tortillis & Seyal & 11,7 & 23,4 & 50 & 16,7 \\
Acacia seyal var fistula & Talh & 5,3 & 13,3 & 40 & 7,6 \\
Acacia albida & Haraz & 1,2 & 2,4 & 40 & 1,7 \\
Ziziphus spina- christi & Sider & 0,9 & 2,3 & 40 & 1,3 \\
Acacia seyal var seyal & Hashab & 0,8 & 2,7 & 30 & 1,1 \\
Balanites aegyptiaca & Higleeg & 0,5 & 1,7 & 30 & 0,7 \\
Acacia mellifera & Kiter & 0,4 & 4 & 10 & 0,6 \\
Prosopis juliflora & Miskiat & 0,3 & 1,5 & 20 & 0,4 \\
\hline
\end{tabular}

Source: Field Survey (2017)

\section{Changes in forest cover according to Land sat 1973}

From the Land sat image of 1973 we note that the forest cover in the study area was dense and is occupying a large area of the total study area, $\left(476,958 \mathrm{~km}^{2}\right)$ (Figure 4).

\section{Forest cover in 2001}

The forest cover in 2001 in the study area decreased in area. It reached $79.785 \mathrm{~km}^{2}$ (Figure 5). This is because of many factors. These factors include the practices of over-logging for fuel and construction in addition to overgrazing and lack of control from side of forest management.

\section{Forest cover in 2016}

Figure 6 shows that the forest cover in the whole study area in 2016 was $99,501 \mathrm{~km}^{2}$. It seems that at that time the level of awareness was high and the supervisory role of forest management was active and potent.

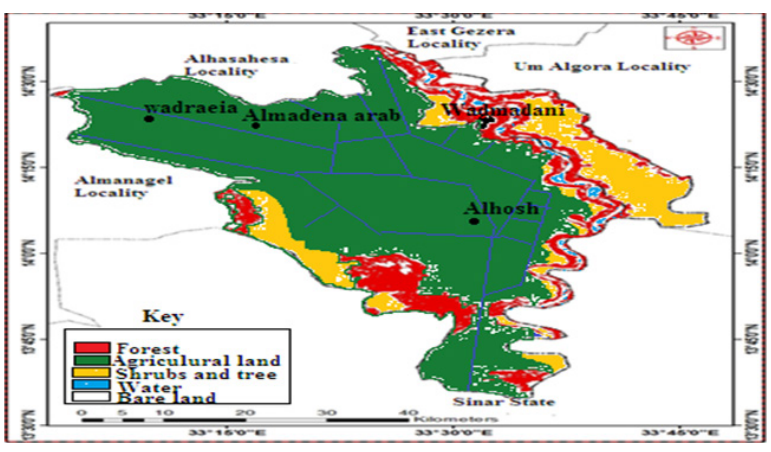

Figure 4 Forest cover in 1973.

Source: American Satellite Land sat 1973.

\section{Changes in forest cover using GIS and remote sensing}

Comparing the area of forests for the three periods (1973-20012016), we note that the forests in 1973 were dense and covered a large area. In 2001, the area shrank dramatically, while in 2016, it increased slightly compared to what it was in 2001 . We can conclude from this that there is density, distribution and cover area of forests show clear fluctuations. Nevertheless, the total lost area of forest cover in the study area amounted to $377.4569 \mathrm{~km}^{2}$ ) (Table 5).

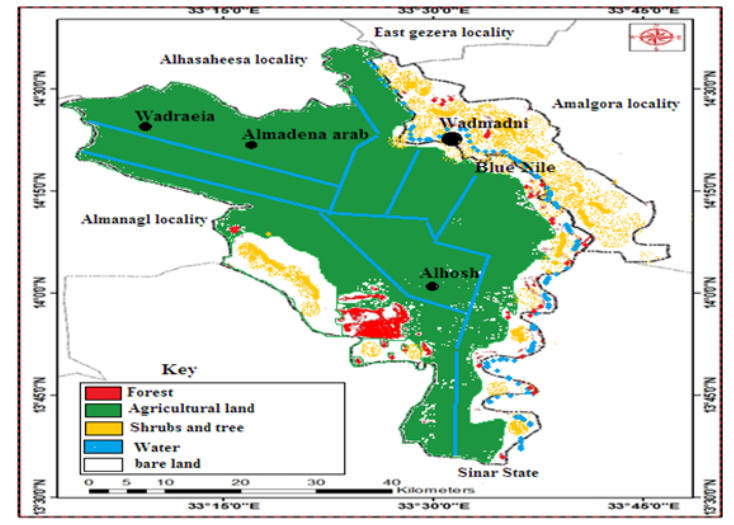

Figure 5 Forest cover in (200I).

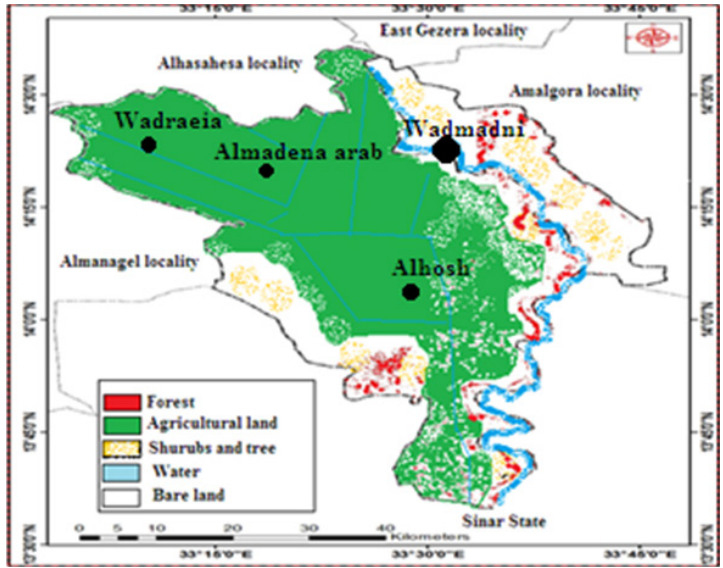

Figure 6 Forest cover in (2016).

Source: American Satellite Land sat (2016). 
Table 5 Percentage of forest distribution for THE Years 1973, 200I and 2016

\begin{tabular}{lllll}
\hline Total area & Forests\% 1973 & Forests\% 200I & Forests\% 2016 & Lost forests I973-20 I6 \\
\hline $476,958 \mathrm{~km}^{2}$ & $14.7 \mathrm{~km}^{2}$ & $2.5 \mathrm{~km}^{2}$ & $3.1 \mathrm{~km}^{2}$ & $377.446 \mathrm{~km}^{2}$
\end{tabular}

Source: analysis of American satellite images- land sat, 5-7

From Table 5, it can be seen that the area lost from large forests in 1973 was $397.1729 \mathrm{~km}^{2}$ which amounts to $14.7 \%$ of the total forest cover, while in 2001 it reached $2.5 \%$ and increased in 2016 to $3.1 \%$. Recently, it can be seen that the forest area increased to $19,716 \mathrm{~km}^{2}$ despite the losses between 1973 and 2016 which amounted to $377,456 \mathrm{~km}^{2}$

\section{Changes in forest diversity}

The forests in the study area were dense and varied and covered a large area. This was confirmed by satellite images for the year 1973 (Figure 2) and field work during 2018. Comparison of the two images reveals that there were more than ten species in the past which indicates that the forest cover was better than at present. However, the results of the inventory in 2018 (Table 3) confirm that the prevailing species at the present time are not more than 4 species. The most dominant species of present day in the study area are Acacia nilotica with a cover of $33.3 \%$ and abundance of $22.4 \mathrm{P} / \mathrm{S}$ and density of $22.4 \mathrm{P} / \mathrm{S}$, although these values are is decreasing because forest wood subjected to daily removal.

\section{Economic and environmental changes resulting from forest changes}

One of the results of the field work (2018) was that the forests in the study area are 'actually located and distributed 'along the banks of the Blue Nile and around villages and cities in distances ranging from $1-5 \mathrm{~km}$. These locations made forests accessible to the population who used for long times back to depend on logging them and collecting their products. Field surveys reveal that $43 \%$ of wood is used by the population for fuel, $34 \%$ of forest wood is of used in the manufacture of building materials, $32 \%$ in home furniture, $19.5 \%$ in traditional industries and $14.5 \%$ in other industries. However, this situation changed after the degradation of forests, where logging began to disappear and the dependence on forest products and forest- related professions became almost deserted.

The decrease in the biodiversity of trees and shrubs triggered a decrease in bird species. In the past, here were more than 25 species and the forests in the region formed an important sanctuary for migratory and seasonal birds. In addition, the removal and deterioration of forests, especially around villages and cities enhanced sand deflation and increased runoff. This is not to mention the significant reduction in recreational activities in which forests entertained a privileged place. ${ }^{15}$

\section{Results}

A. Based on digital assessment of the forest cover in the study area in the period 1973-2016, it can be identified that the cover underwent some fluctuations. In the past, Images show that the forest cover occupied a larger area and was denser and the species variability was higher.

B. Forests in the region suffer from decimation and environmental degradation. The proportion of forests in 1973 was 14.7\%), in
$20012.5 \%$ and in 2016 increased to only $3.1 \%$ of the total area of the region.

C. Forest decimation and degradation is attributed to the reliance of population on forest wood to cover their needs on fuel, construction and traditional industries. However, the situation is expected to change as a result of prevalence of Gas and electricity.

D. The decimation of forest cover affected the habitats and sanctuaries of birds, local and migratory, and reduced the value of forest as a recreation place for the population. ${ }^{16-18}$

\section{Recommendations}

1) Forest legislations must be activated in order to protect forest cover from overgrazing, and indiscriminate logging.

2) A comprehensive environmental database must be established for land use maps which necessarily include maps forest cover in order to assist decision makers and planners.

3) Adoption of a program of follow-up using modern techniques such as remote sensing and GIS to ensure monitoring of changes and protection and conservation and development of degraded areas.

4) Promotion of environmental awareness among the local population through various media.

5) Achieving sustainable development in future forest-related development plans.

\section{Acknowledgments}

None.

\section{Funding}

None.

\section{Conflicts of interest}

The authors declare there are no conflicts of interest.

\section{References}

1. Harrison MN, Jackson JK. Ecological classification of the vegetation of the Sudan. Forest Bull. No 2. (New series) Forest Department, Khartoum; 1958.

2. Elsiddig EA, Mohamed AG, Abdel Magid TD. Sudan forestry sector review. Forests National Corporation and National Forest Programme Facility; 2007

3. FAO and FNC. National forests inventory for Sudan 1998. (GCP/ SUD/047/NET); 1998

4. FAO. Guidelines on sustainable forest management in dry lands of subSaharan Africa. Arid Zone Forests and Forestry Working Paper No. 1; 2010. 
5. Abdelsalam A, Ahmed SM, Suliman E, et al. Consumption of energy. Household sector. National Assessment for Energy in Sudan. Ministry of Energy and Mining. 2000

6. El Atta HA, Abdel Nour HO. Forest pests in the Sudan: their economic importance and control. In: Nshubemuki L, editor. Workshop Proceedings. Leucaena psyllid: a threat to agroforestry in Africa. Morogoro, Tanzania: Tanzania Forestry Research Institute; 1995:82-91.

7. Gaafar A. The management of Acacia nilotica plantation along the Blue Nile, South of Sinner Dam through successive rotation (1935-2006). M Sc. thesis, Faculty of Forestry, University of Khartoum; 2008.

8. Abdel Magid TD, Warrag EI. Status and experience of agroforestry in Sudan. Eco-forum. Sudanese Environment Conservation Society and NOVEB. 2011.

9. Bayoumi AMS, Badi KH, El Houri A, et al. A century of Sudanese forestry. Forests National Corporation; 2001.

10. Semizoglu MA, Abdel Magid TD. Potential areas of irrigated forest plantations in Sudan, with special reference to central Sudan. Plantation Section, Fuelwood Development Energy Project. Sudan Government; 1986.
11. Abdel Magid TD. The potential of irrigated forest plantations in Sudan. National Nile Basin Forum, Ministry of Irrigation and Water Resources. Nile Basin Initiative; 2008.

12. Al-Tarifi M. The investment map in the field of agricultural production. Gezira University Press, Gezira State, Sudan: Wad Madani; 1995.

13. Adam H Suleiman. The agricultural climate in Gezira Project. Gezira University Press, Gezira State, Sudan: Wad Madani; 2005.

14. Central Statistical Organization. Gezira State, Sudan: Wad madani 2005 .

15. El wakeel AS. Status of biodiversity in Sudan. Eco-forum. Sudanese Environment Conservation Society and NOVEB; 2011.

16. Forest Management. Land and water survey report, Gezira State; 1978.

17. Gharaibeh, Al-Farah, Samih, et al. Introduction to environmental sciences. Amman, Jordan: Dar Al-Shoroog Publishing; 1991.

18. National Forestry Administration. 1983. 